\title{
A scientific study of the pigments in the wall paintings at Jokhang Monastery in Lhasa, Tibet, China
}

\author{
Zhimin $\mathrm{Li}^{1,2 \dagger}$, Lele Wang ${ }^{3+}$, Qinglin $\mathrm{Ma}^{3^{*}+}$ and Jianjun $\mathrm{Mei}^{2+}$
}

\begin{abstract}
Knowledge about pigments applied in ancient wall paintings is of great importance in art conservation and art history. In this study, fifteen pigment samples from the wall painting on the pilgrimage-corridor at the Jokhang Monastery in Lhasa, Tibet were analyzed, using different techniques, including X-ray fluorescence (XRF), Raman microspectroscopy (Raman), polarized light microscopy (PLM), and scanning electron microscopy with energy dispersive X-ray spectrometry (SEM-EDS). It is found that azurite, malachite, red lead, cinnabar, mars red, orpiment, gold, calcite, magnesium carbonate, barium white, especially modern synthetic Ultramarine blue, emerald green, chrome yellow and lithopone were used as colorants on plaster. This result suggests that the wall painting may have been executed after the 1850s, mostly in about the 1900s.
\end{abstract}

Keywords: Tibet, Wall painting, Modern synthetic pigments, Raman microscopy

\section{Introduction}

The identification of pigments is one of the most important analytical tasks in the characterization of ancient paintings, as it provides a rich source of information about the provenance, date of production, development of painting traditions, and trade of the pigments. Pigments and other materials applied by painters are also of great importance in art history and for art conservation. They are particularly crucial for selecting the most appropriate materials and methods for art restoration.

Various methods have been applied in the identification of pigments and media binder in the ancient Chinese paintings and relevant cultural relics according to their performance advantages [1-3]. Over the past few years, a few research projects have focused on the identification of pigments and techniques in the wall paintings or Thangka paintings in Tibet, offering interesting scenarios and findings. According to previous scientific investigations, emerald green, Scheele green and orpiment were listed as typical pigments used for Tibetan Thangka paintings

\footnotetext{
* Correspondence: qinglinma226@126.com

${ }^{\dagger}$ Equal contributors

${ }^{3}$ Chinese Academy of Cultural Heritage, 2 Gaoyuan Street, Chaoyang District, Beijing 100029, P R China

Full list of author information is available at the end of the article
}

(15th-19th century) [4]. Azurite, malachite, red lead and cinnabar were identified in the wall paintings in the Potala Palace and the Norbuglinkha and Sa-Skya Monastery in Tibet in 2002 [5]. More recently, Raman microscopy was used in the recognition of pigments in Tibetan paintings. In 2010, Azurite, malachite, red lead, cinnabar, orpiment and gypsum were found in a Tibetan Thangka painting of the 18th century at the Derge Monastery with a mobile Raman probe [6]. Recently, pigment samples from the wall paintings of the 15th century at the Tsokchen Chanting Hall of the Drepung Monastery were identified as cinnabar, iron red, malachite, azurite, orpiment, chalk and carbon [7], while pigments from the Palcho Monastery were identified as cinnabar, iron yellow, malachite, azurite, chalk and carbon [8].

The Chinese Academy of Cultural Heritage is currently undertaking some restoration projects for the wall paintings at the Jokhang Monastery in Lhasa, Tibet Autonomous Region. The present work aims to explore the techniques of wall paintings using multi-analytical methods, including pigments and painting techniques, which could provide crucial scientific data for art restoration and art history. In order to sustain their religious function, Tibetan wall paintings were always repainted even when they were only partly damaged. Due to the lack of necessary 
documentation on these restoration processes, their repainting dates became unknown to modern researchers. Therefore, a scientific investigation of the pigments and their manufacturing techniques might offer us the clues to determine when they were repainted.

\section{Results and discussions}

\section{XRF analysis of pigment samples}

The results obtained from the XRF analysis are summarized in Table 1 . The samples of DZ12-DZ15 were taken from the wall painting by scalpel and just in powdery particles and contain a lot of mud, so they cannot be analysed by XRF.

\section{PLM analysis of pigment particles}

Microtextural features of the pigments were observed under polarized light microscopy.

The shapes of emerald green (Figure 1A), Ultramarine blue (Figure 1B) and chrome yellow (Figure 1C) particles were regular; their grain sizes were even and smooth. However, orpiment particle (Figure 1D), showed a euhedral and irregular shape; its grain size was uneven; it was foliated and its luster was pearly on the cleavage surface. This is the typical shape of natural minerals. Therefore, it can be inferred that emerald green, Ultramarine blue and chrome yellow are artificial pigments.

\section{Raman spectroscopic analysis of pigment samples White ground layer}

The white ground layer yielded the characteristic Raman bands of calcium carbonate $\left(\mathrm{CaCO}_{3}\right)$, which was found in every sample except DZ12, DZ13, DZ14. Magnesium carbonate $\left(\mathrm{MgCO}_{3}\right)$ was detected in DZ2, DZ3, DZ8, DZ15. Meanwhile, lithopone $\left(\mathrm{ZnS}\right.$ and $\left.\mathrm{BaSO}_{4}\right)$ appeared in DZ5.

\section{Blue pigment}

The XRF examination of the blue pigment (DZ1, DZ4) revealed relatively high content of $\mathrm{Cu}$, suggesting that blue pigment could be azurite. This, however, was not confirmed by the Raman measurement. The Raman spectrum showed the Ultramarine blue $\left(\mathrm{Na}_{7} \mathrm{Al}_{6} \mathrm{Si}_{6} \mathrm{O}_{24}\right.$ $\left(\mathrm{S}_{\mathrm{n}}{ }^{-}\right)$)(Figure $\left.2 \mathrm{~A}\right)$, coexisting with malachite $\left(\mathrm{CuCO}_{3} \cdot \mathrm{Cu}\right.$ $\left.(\mathrm{OH})_{2}\right)$. Azurite $\left(2 \mathrm{CuCO}_{3} \cdot \mathrm{Cu}(\mathrm{OH})_{2}\right)$ was indeed identified in the samples of DZ3 and DZ15.

\section{Green pigment}

The green aura of Buddha Sakyamuni was painted with emerald green $\left(\mathrm{Cu}\left(\mathrm{C}_{2} \mathrm{H}_{3} \mathrm{O}_{2}\right) \cdot 3 \mathrm{Cu}\left(\mathrm{AsO}_{2}\right)_{2}\right)$ as shown in Sample DZ3 (Figure 2B).

\section{Yellow pigment}

One yellow pigment (Sample DZ5) yielded the spectrum of chrome yellow $\left(\mathrm{PbCrO}_{4}\right)$ (Figure $2 \mathrm{C}$ ), yet coexisting with bands of lithopone. Another yellow pigment (DZ13) found here was orpiment $\left(\mathrm{As}_{2} \mathrm{~S}_{3}\right)$ (Figure 2D).

\section{Orange pigment}

The orange-red parts of the Buddha Sakyamuni's cloth closely matched the spectrum of red lead $\left(\mathrm{Pb}_{3} \mathrm{O}_{4}\right)(\mathrm{DZ7}$, DZ11, DZ12).

\section{Red pigment}

Cinnabar (HgS) (DZ9, DZ10) and mars red $\left(\mathrm{Fe}_{2} \mathrm{O}_{3}\right)$ (DZ11) were detected as very common pigments that occur virtually in Tibetan paintings.

\section{SEM-EDS analysis of pigment samples}

The cross-section of Sample DZ7 with orange paints is shown in Figure 3. The protective glue layer, pigment layer and white ground layer can be clearly seen from the left to the right in this figure. The SEM-BSE micrograph provides more information, and the white ground

Table 1 XRF results of pigment samples

\begin{tabular}{|c|c|c|c|c|c|c|c|c|c|c|c|c|c|c|c|c|c|c|c|c|c|}
\hline \multirow{2}{*}{$\begin{array}{l}\text { Sample } \\
\text { no. }\end{array}$} & \multirow[t]{2}{*}{ Color } & \multicolumn{19}{|c|}{ Elements detected by XRF(Wt\%) } & \multirow[t]{2}{*}{ Possible pigments } \\
\hline & & $\mathrm{Cu}$ & As & $\mathrm{Hg}$ & $\mathrm{Fe}$ & $\mathrm{Pb}$ & $\mathrm{Cr}$ & $\mathrm{Au}$ & $\mathrm{Ag}$ & $\mathrm{Ca}$ & $\mathrm{Zn}$ & $\mathrm{Ba}$ & $S$ & $P$ & $\mathrm{~K}$ & Si & $\mathrm{Sr}$ & V & $\mathrm{Ti}$ & $\mathrm{Sc}$ & \\
\hline DZ1 & Blue & 42.7 & -- & --- & 3.2 & -- & --- & -- & -- & 10.0 & 8.7 & 8.9 & 24.3 & -- & 2.2 & --- & --- & -- & -- & --- & Azurite \\
\hline $\mathrm{DZ2}$ & Gold & 8.4 & --- & --- & 11.5 & 2.6 & --- & 7.3 & 1.0 & 23.1 & 19.5 & 15.2 & 4.0 & 3.8 & -- & --- & 1.6 & --- & -- & -- & Gold \\
\hline DZ3 & Green & 53.2 & 10.4 & --- & 1.4 & 1.1 & --- & -- & -- & 10.7 & 1.0 & -- & 8.5 & 6.9 & 0.7 & --- & 0.3 & --- & -- & --- & Malachite, Emerald green \\
\hline DZ4 & Blue & 84.4 & --- & --- & 0.8 & 1.5 & -- & -- & -- & 7.5 & -- & 5.6 & 5.0 & --- & 0.4 & -- & --- & --- & --- & -- & Azurite \\
\hline DZ5 & Yellow & 0.5 & --- & --- & 4.1 & 1.5 & 1.2 & -- & --- & 19.2 & 10.1 & 24.9 & 22.1 & --- & -- & --- & 0.3 & --- & --- & --- & Chrome yellow \\
\hline DZ6 & Orange & --- & --- & --- & 1.3 & 36.1 & 1.2 & & -- & 11.7 & --- & 37.4 & -- & 4.5 & 1.4 & & 0.6 & 3.3 & --- & 0.5 & Read lead \\
\hline DZ7 & Orange & 0.3 & --- & --- & 0.6 & 69.7 & 0.5 & -- & --- & 6.4 & 0.6 & 19.2 & --- & --- & -- & 2.3 & --- & --- & --- & --- & Read lead \\
\hline DZ8 & Gold & --- & --- & --- & 1.3 & --- & --- & 0.3 & --- & 27.6 & 0.4 & 3.1 & 29.0 & 25.5 & --- & --- & --- & --- & --- & --- & Gold \\
\hline DZ9 & Red & 0.2 & --- & 49.6 & -- & 2.2 & --- & -- & -- & 16.3 & -- & 13.5 & 10.5 & 7.8 & --- & -- & --- & --- & -- & -- & Cinnabar \\
\hline DZ10 & Red & 0.4 & --- & 25.8 & 0.9 & 0.3 & --- & -- & --- & 37.6 & 0.4 & --- & 32.9 & -- & --- & --- & --- & --- & 1.3 & --- & Cinnabar \\
\hline DZ11 & Red & --- & --- & --- & 7.5 & 48.4 & --- & --- & --- & 39.7 & --- & --- & --- & --- & --- & --- & --- & --- & 4.2 & --- & Read lead, Mars red \\
\hline
\end{tabular}



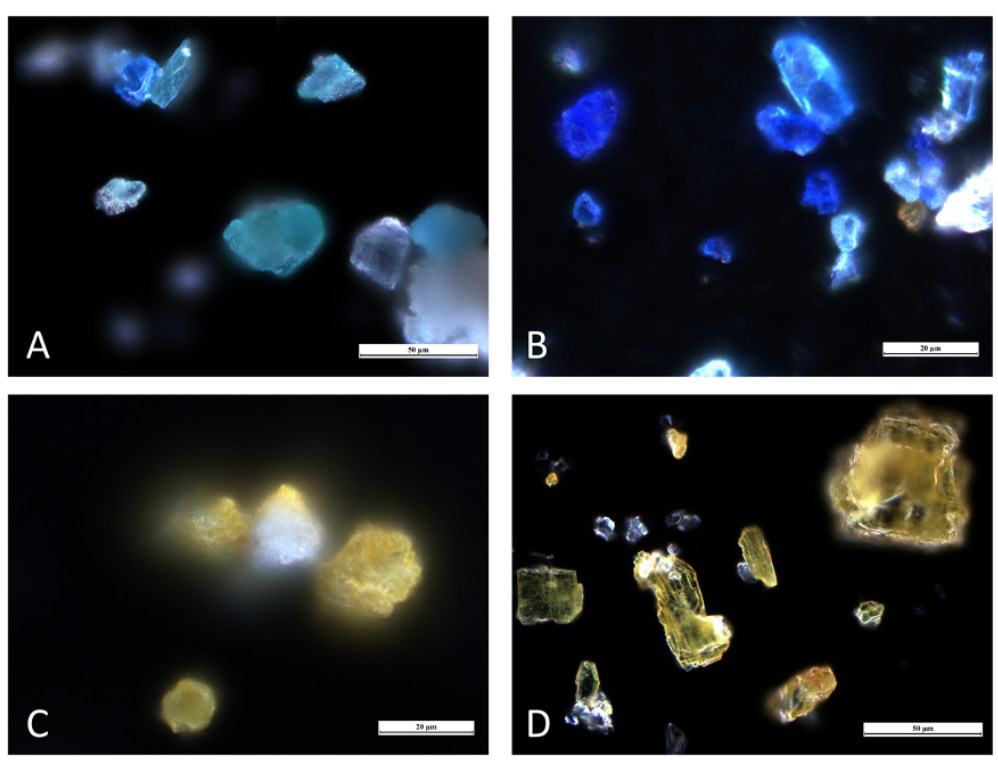

Figure 1 The morphology of pigment particles. (A) DZ3, emerald green. (B) DZ4, Ultramarine blue. (C) DZ5, chrome yellow. (D) DZ13, orpiment.
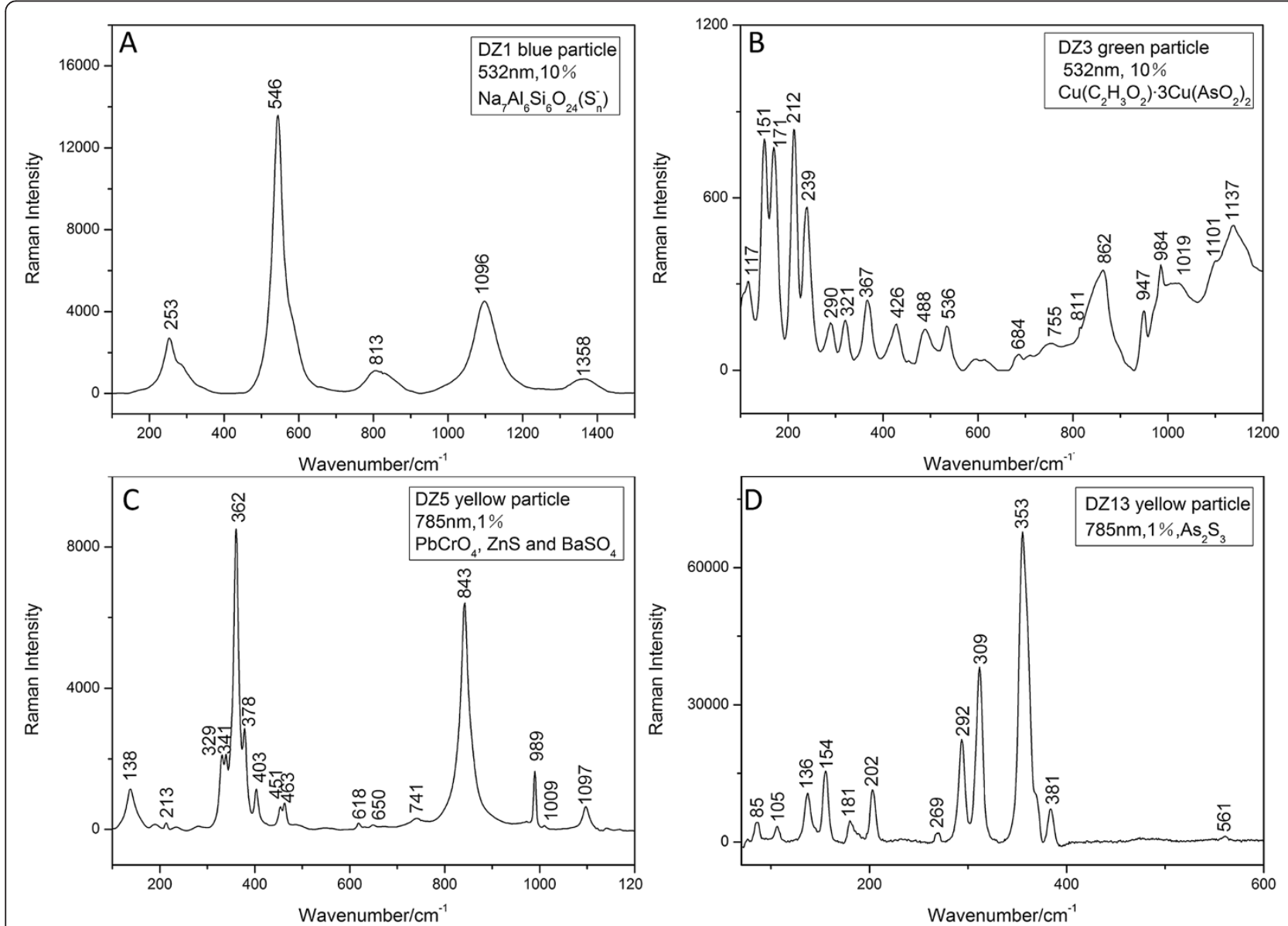

Figure 2 Raman spectrum of pigment samples. (A) DZ1, Ultramarine blue. (B) DZ3, emerald green. (C) DZ5, mixture of chrome yellow and lithopone. (D) DZ13, orpiment. 


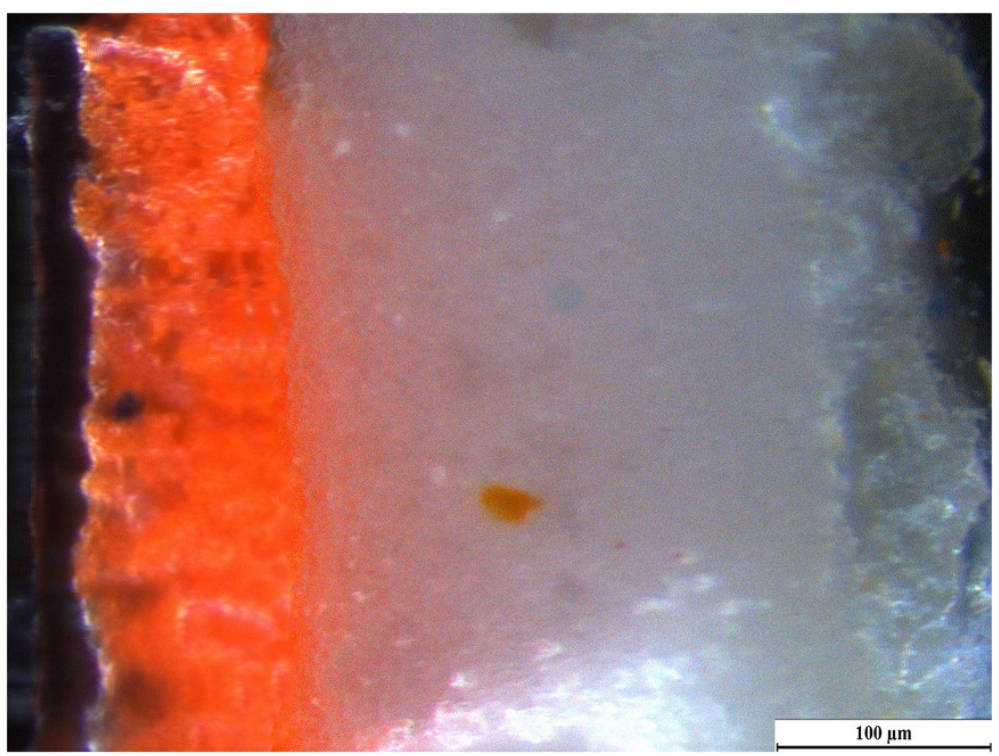

Figure 3 The cross-section of Sample DZ7: optical photomicrograph.

layer seen in Figure 3 can be further divided into two layers in Figure 4.

Table 2 shows the results of EDS compositional analysis. It reveals that the techniques used for wall paintings apparently vary between Tibet and other places in China. The final step of finishing the wall paintings is glue coating in order to protect the paintings. The relatively high content of carbon in the region marked $\square \mathrm{A}$ in Figure 4 indicates that the protective varnish layer may be organic glue. Point $+\mathrm{B}$ consists of $\mathrm{Ba}, \mathrm{S}$ and $\mathrm{O}$, and it can be assumed as barium white. $\mathrm{Pb}$ was detected in point $+\mathrm{C}$, indicating the presence of red lead. Lithopone
( $\mathrm{ZnS}$ and $\mathrm{BaSO}_{4}$ ) is assumed to exist due to the detection of $\mathrm{Ba}, \mathrm{S}$ and $\mathrm{Zn}$, as shown in spot $+\mathrm{F}$. Regions marked $\square \mathrm{G}$, the presence of $\mathrm{Al}, \mathrm{Si}, \mathrm{O}, \mathrm{Ba}, \mathrm{Zn}, \mathrm{S}, \mathrm{K}, \mathrm{Na}, \mathrm{Mg}$ and $\mathrm{Ca}$ were mainly contributed by the components of clays and lithopone.

\section{Modern synthetic pigments used in wall paintings}

In this work, we have found that Tibetan artists used not only traditional mineral pigments but also many artificially synthetic pigments, i.e. Ultramarine blue, emerald green, chrome yellow and lithopone.

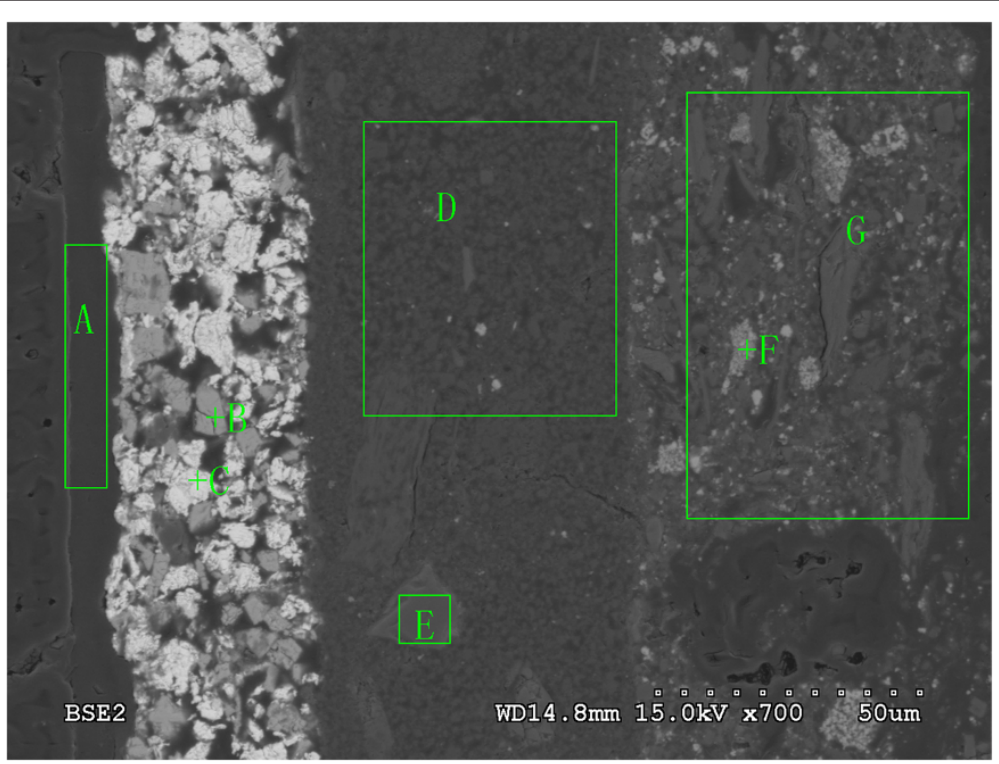

Figure 4 The cross-section of Sample DZ7: SEM-BSE micrograph. 
Table 2 SEM-EDS results of orange pigment sample DZ7

\begin{tabular}{|c|c|c|c|c|c|c|c|c|c|c|c|c|}
\hline \multirow{2}{*}{$\begin{array}{l}\text { Analysis } \\
\text { position }\end{array}$} & \multicolumn{12}{|c|}{ Elements detected by EDS (Wt\%) } \\
\hline & $\mathrm{C}$ & 0 & $\mathrm{Na}$ & $\mathrm{Mg}$ & Al & $\mathrm{Si}$ & $S$ & $\mathrm{~K}$ & $\mathrm{Ca}$ & $\mathrm{Zn}$ & $\mathrm{Pb}$ & $\mathrm{Ba}$ \\
\hline A & 80.9 & 15.1 & --- & --- & --- & --- & --- & --- & 4.1 & --- & --- & --- \\
\hline B & 6.6 & 12.4 & --- & --- & --- & --- & 13.9 & --- & --- & --- & -- & 67.1 \\
\hline C & 2.9 & 2.9 & --- & --- & 1.2 & --- & --- & --- & --- & --- & 93.0 & --- \\
\hline $\mathrm{D}$ & 43.6 & 23.1 & --- & 23.1 & 3.9 & 6.4 & --- & --- & --- & --- & --- & --- \\
\hline E & 10.3 & 27.3 & --- & --- & 2.7 & 59.7 & --- & --- & --- & --- & --- & --- \\
\hline F & 9.6 & 7.8 & 5.0 & --- & 2.4 & 0.9 & 14.0 & --- & --- & 13.1 & --- & 47.4 \\
\hline $\mathrm{G}$ & 28.3 & 20.6 & 1.6 & 1.2 & 11.3 & 11.3 & 5.2 & 3.3 & 1.1 & 5.3 & --- & 11.0 \\
\hline
\end{tabular}

Lead chromate was first synthesized by French Chemist Vauquelin in 1809. Germany began the industrial production of chrome yellow in 1818, America in 1900 and China in 1924 [9]. Chrome yellow began to be widely used as a pigment in watercolors, coach paintings and oil paintings in the second quarter of the 19th century [10]. Lithopone was invented in early 19th century [11] and gained popularity in the 1870s [12]. Emerald green, which was first formulated in Germany in 1814 as stated by the famous Chinese Artist Fei'an Yu, was widely used in China as watercolor in pith paper works and in scroll paintings from the 1850s onwards [13].

The scientific investigations revealed that chrome yellow was used as yellow pigment in the Niche of the Qing Dynasty Tomb at Xihe Site in Zhangqiu, Shandong Province [14]. Emerald green was applied in Drum Tower (past restoration material) in Xi'an, Shaanxi Province [11], the Cave 12 of Yungang Grottoe, Shanxi Province [15] as well as the portrait of the Chinese Taoist Figure [16] and Zhendu Men in the Palace Museum, Beijing [17]. Ultramarine blue was largely used in Mogao Grottoes, Dunhuang, Gansu Province [18]. J. Mass found that Tibetan Thangka paintings of the late 19th and early 20th centuries used Western pigments, such as emerald green, ultramarine blue, and chrome yellow [19].

Historical records indicate that during the $1840 \mathrm{~s}$ the pigments imported into Nepal and then into Tibet by the British East India Company included lead white, indigo, verdigris and sandalwood [19]. European synthetic paints may have been introduced into Tibet, via India or central China, and their availability and affordability probably increased in the early 20th century [20]. Above all, the synthetic pigments applied in the wall paintings were most likely introduced into Tibet no earlier than the $1850 \mathrm{~s}$.

\section{Conclusions}

In this project, fifteen pigment samples taken from the wall painting on the pilgrimage-corridor at the Jokhang Monastery in Tibet were analyzed using Raman spectroscopy, XRF, PLM, and SEM-EDS. The results show that azurite, malachite, red lead, cinnabar, mars red, orpiment, gold, calcite, magnesium carbonate, barium white, especially modern synthetic Ultramarine blue, emerald green, chrome yellow and lithopone were applied as single or mixture pigments.

Considering the time when these synthetic pigments were imported to and applied in central China and the Tibetan region, it can be inferred that the repainting of these wall paintings should have been executed after the 1850 s and mostly in about the 1900s.

\section{Methods}

\section{Samples}

Fifteen pigment samples, taken from the wall paintings on the pilgrimage-corridor at the Jokhang Monastery, were extracted, prepared and analyzed. The samples are listed as DZ1-DZ15 in Table 1.

\section{Characterization}

The X-ray fluorescence (XRF) analysis was conducted by using the Japanese instrument of SHMADZU EDX-800HS.

The Raman spectroscopic analysis was undertaken by using an Xplora spectrometer made by the French Horiba Jobin Yvon Company. The laser light was focused through the objective $(\times 20)$ of an Olympus BX-41 microscope.

The microscopic investigations were carried out by a German Leica DM4000M microscope.

The SEM-EDS analysis was operated with a Hitachi S$3600 \mathrm{~N}$ with EDAX Genesis 2000XMS to determine the elements of each layer of the sample (DZ7-Orange). All samples were sputter-coated with gold prior to the analysis.

\section{Competing interests}

The authors declare that they have no competing interests.

\section{Authors' contributions}

QM and JM provided support and guidance for this study. ZL and LW carried out the laboratory experiments, analyzed the data, interpreted the results and drafted the paper. All authors have contributed to, seen and approved the manuscript.

\section{Acknowledgements}

This paper reports some of the results of the project 'Colorants Measurement and Historical Evaluation of the Wall Paintings at the Jokhang Monastery in 
Lhasa, Tibet' under the sponsorship of the Chinese Ministry of Finance's Special Fund for the Basic Research by Non-Profit Public Research Institutes in 2012. The authors are very grateful to Dr. Dawa Shen, Dr. Yu Wang, Ms. Xiaotong Zhang, and Ms. Na Wu of the Chinese Academy of Cultural Heritage, and Ms. Min Luo of the University of Science and Technology Beijing for their kind support and assistance with this research. Thanks are also given to Ms. Wang Hui, senior editor in China Daily, for her help in English writing of this paper.

\section{Author details}

'Shanxi Provincial Technology Centre for Cultural Relics, Taiyuan, China. ${ }^{2}$ The Institute of Historical Metallurgy and Materials, University of Science and Technology, Beijing, China. ${ }^{3}$ Chinese Academy of Cultural Heritage, 2 Gaoyuan Street, Chaoyang District, Beijing 100029, P R China.

Received: 12 March 2014 Accepted: 10 September 2014

Published online: 17 September 2014

\section{References}

1. Wei S, Ma Q, Schreiner M: Scientific investigation of the paint and adhesive materials used in the Western Han Dynasty polychromy terracotta army, Qingzhou, China. J Archaeol Sci 2012, 39:1628-1633.

2. $\mathrm{Ma} \mathrm{Q}$, Berke H: Raman and SEM studies of ancient pigments containing arsenic, sulphur, realgar and pararealgar excavated from Yumen county, Gansu Province, China. Sci Conserv Archaeol 2006, 18:4-8.

3. Kock L, Waal D: Raman studies of the under glaze blue pigment on ceramic artifacts of the Ming Dynasty and of unknown origins. J Raman Spectrosc 2007, 38:1480-1487.

4. Mehra V: Note on the technique and conservation of some Thang-ka paintings. Stud Conserv 1970, 15:206-214.

5. Wang W, Ma Z, Yu Z, Zhao L, Li S, Sun H, Fu Y: An analysis on the materials of murals in Potala Palace, Norbuglinkha and Sa-Skya Monastery, Tibet. Dunhuang Res 2002, 6:78-84.

6. Ernst R: In situ Raman microscopy applied to large Central Asian paintings. J Raman Spectrosc 2010, 41:275-287.

7. Qi N: A Study on the technique about the wall painting's restoration and conservation in the circumanbulation,Tsokchen Chanting Hall of Drepung Monastery. Diss Degree M A Univ Sci Technol Beiijing 2014, 1:39-41.

8. Wang L, Guo H: Studies on the technique of wall paintings at Multi-Door Chorten in Palcho Monastery. China Tibetol 2013, 4:174-180.

9. Du C: Re-understanding of lead chromate pigments. China Coat 2012, 27:4-17.

10. Kühn H, Curran M: Chrome yellow and other chromate pigments in Artists' Pigments. In A Handbook of Their History and Characteristics. Volume 1. Edited by Feller RL. Washington, DC: National Gallery of Art; 1986:187-200.

11. Sánchez Del Río M, Martinetto P, Somogyi A, Reyes-Valerio C, Dooryhée E, Peltier N, Alianelli L, Moignard B, Pichon L, Calligaro T, Dran J: Microanalysis study of archaeological mural samples containing Maya blue pigment. Spectrochim Acta B 2004, 59:1619-1625.

12. Kaszowska Z, Malek K, Pańczyk M, Mikołajska A: A joint application of ATR-FTIR and SEM imaging with high spatial resolution: Identification and distribution of painting materials and their degradation products in paint cross sections. Vib Spectrosc 2013, 65:1-11.

13. Mazzeo R, Cam D, Chiavari G, Fabbri D, He L, Prati S: Analytical study of traditional decorative materials and techniques used in Ming Dynasty wooden architecture. The case of the Drum Tower in Xi an, P.R. of China. J Cult Herit 2004, 5:273-283.

14. Xu J, Wang W, Xia Y: The extraction and colored pigments analysis of the niche of the Qing Dynasty tomb found in Xihe site, Zhangqiu of Shandong Province. In Preservation of Cultural Relics. Volume 2. Beijing: Cultural Relics Press; 2010:285-290.

15. Zhou G, Cheng H: Analysis of the pigments on the wall painting in Yungang Caves. Archaeol 1990, 10:948-951.

16. He Q, Li T, Shi J, Zhao R, Li Y, Shao F: Non-destructive in-situ characterization of pigments on a portrait of Chinese Taoist figure. Sci Conserv Archaeol 2010, 22:61-68.

17. Cheng $X$, Xia $Y$, Ma $Y$, Lei $Y$ : Three fabricated pigments (Han purple, indigo and emerald green) in ancient Chinese artifacts studied by Raman microscopy, energy-dispersive X-ray spectrometry and polarized light microscopy. J Raman Spectrosc 2007, 38:1274-1279.

18. Wang J: Study on synthetic Ultramarine blue in Dunhuang. Dunhuang Res 2000, 1:76-81.
19. Mass J, Huang J, Fiske B, Shaftel A, Zhang X, Laursen R, Shimoda C, Matsen C, Bisulca C: Thangka production in the $18^{\text {th }}-21^{\text {st }}$ centuries: documenting the introduction of non-traditional materials into Himalayan painting practice. ICOM Comm Conserv 2009, 2:206-210.

20. Price B, Malenka S, Sutherland K, Cuffari K, Paul K, Kingery A, Zhang X: A Tibetan polychrome domestic altar and four six-panel cabinets: materials analysis, implications for dating, and conservation treatment. ICOM Comm Conserv 2008, 2:832-838.

doi:10.1186/s40494-014-0021-2

Cite this article as: Li et al:: A scientific study of the pigments in the wall paintings at Jokhang Monastery in Lhasa, Tibet, China. Heritage Science 2014 2:21.

\section{Publish with ChemistryCentral and every scientist can read your work free of charge \\ "Open access provides opportunities to our colleagues in other parts of the globe, by allowing anyone to view the content free of charge." W. Jeffery Hurst, The Hershey Company.}

- available free of charge to the entire scientific community

- peer reviewed and published immediately upon acceptance

- cited in PubMed and archived on PubMed Central

- yours - you keep the copyright

Submit your manuscript here:

http://www.chemistrycentral.com/manuscript/<smiles>c1ccccc1</smiles>

ChemistryCentral 